\title{
BOTANICAL SURVEY OF MEDICINAL PLANTS USED IN THE TRADITIONAL TREATMENT OF HUMAN DISEASE IN MONTAIN HAY MEADOWS FROM GURGHIULUI MOUNTAINS
}

\author{
Silvia OROIAN ${ }^{1 *}$, Mihaela SĂMĂRGHIŢAN ${ }^{2}$, Sanda COŞARCA ${ }^{1}$, Mariana HIRIŢIU ${ }^{1}$, \\ Florentina OROIAN ${ }^{3}$, Corneliu TANASE ${ }^{1}$ \\ ${ }^{1}$ Department of Fundamental Pharmaceutical Sciences, Discipline of Pharmaceutical Botany, University of \\ Medicine, Pharmacy, Sciences and Technology of Târgu Mureș, Romania \\ ${ }^{2}$ Mureş County Museum, Department of Natural Sciences, Târgu Mureş, Romania \\ ${ }^{3}$ The Pharmacy Remedia Târgu Mureş, Romania
}

*Correspondence:

Silvia OROIAN

oroianslv@yahoo.com

Received: 14 May 2019; Accepted: 15 June 2010; Published: 30 June 2019

\begin{abstract}
The aim of this study was to identify the medicinal and aromatic plants from mountain hay meadows (6520 - Natura 2000 habitat) of Gurghiului Mountains and to analyze the correlation of these herbs with their therapeutic compounds as well as the human diseases on which they can be used on therapeutic purpose. The area covered by this study was the Gurghiului Mountains. Regarding the vegetation, this area is characterized by the predominance of forest ecosystems, along with semi-natural mountainous grasslands. The floristic inventory for the studied area included numerous medicinal plants with therapeutic chemical compounds. These medicinal plants were grouped in this study according to the dominant active principles used in phytotherapy. Two plant associations were identified: Festuco rubrae-Agrostietum capillaris Horvat 1951 and Poo-Trisetetum flavescentis Knapp ex Oberdorfer 1957. This survey demonstrates that the medicinal plant area in the Gurghiului Mountains is a promising economic resource for developing this region, but it needs planned exploitation.
\end{abstract}

Keywords: grasslands, habitats, medicinal plants.

\section{Introduction}

Today is increasing interest in the health benefits of medicinal plants. This is with good reason as they might offer a natural safeguard against the development of certain conditions and be a putative treatment for some diseases (Tahraoui et al., 2007). Ethnobotanical studies have become increasingly valuable in the development of health care and conservation programs (Nadembega et al., 2011; Wright et al, 2007; Tahraoui et al., 2007). The green pharmaceuticals are receiving extraordinary importance and popularity. Ethnobotany and ethnopharmacology have contributed to the discovery of many important plant-derived drugs.

Vegetal product research can be guided by ethnopharmacological knowledge. In the same time, it can make a contribution to drug innovation by providing novel chemical structures and/or mechanisms of action. Both plant-derived drugs and crude plants have to take the same pharmaco-economic hurdle that 
has become important for new synthetic drug (De Smet, 1997).

An increased interest worldwide for the estimation of therapeutic potential of herbal medicine, prompted us to study grasslands with plants showing medicinal potential, especially herbs used in a variety of human disorders. Sustainable use of wild populations of medicinal plants requires robust assessment of the distribution and abundance of target species (Nkomo et al., 2014). In different countries, many medicinal plants are widely distributed and used across regions. However, relatively few are cultivated. Thus, the conservation of these plants requires efforts that are directed to key habitats, including secondary forests, disturbed areas and agrolandscapes (AguilarStøen and Moe, 2007).

Medicinal plants growing in semi-natural and natural ecosystems are a valuable commodity because they are a cheap resource; the quality of spontaneous herbs is seldom superior to those cultivated and their consumers acceptance is higher.

Our study represents an inventory on medicinal plants identified in the mountain hay meadows from the area of the Gurghiului Mountains. The collected data represent the preliminary information required in view of a future phytochemical investigation on the most used plants.

\section{Materials and Methods}

\subsection{Study area}

Gurghiului volcanic mountains are on the western edge of the Eastern Carpathians Center (Mureş County). They fall into the group of the youngest mountains in Romania. By their geographical location they fall in the temperate mountains, wet and cool climate. This climate together with edaphic conditions is responsible for the richness and diversity of flora existing in the study area.

\subsection{Botanical survey}

The survey was carried out during the year 2014-2015 and subsequent data analysis that was completed in 2016. The study of medicinal plants was done in Natura 2000 habitat, 6520 Mountain hay meadows, comprising seminatural mountain meadows. This study of medicinal plants was carried out based on our own research in the field by using classic techniques, procedures promoted in literature, and some statistical analysis (Oroian, 1998; Sămărghiţan et Oroian 1999; Tămaș, 1999; Oroian et Sămărghiţan, 2000; Sămărghiţan, 2005; Oroian, 2011; Coldea, 2012; Rácz et al, 2012).

The type of habitat has been coded in accordance with existing interpretations of habitats in Romanian manuals (Cristea et al., 2004; Gafta et Mountford, 2008). Habitat structure characterization was done using phytosociological surveys. The inventory of the medicinal species was based on the active principles contained therein, and data obtained from bibliographic information (Istudor, 1998; Palade, 1998; Sămărghiţan et Oroian 1999; Tămaș, 1999; Oroian et Sămărghiţan, 2000; Istudor, 2001; Palade et al, 2003; Cristea et al., 2004; Doniță et al. 2005; Aguilar-Støen et Moes, 2007; Gafta et Mountford, 2008; Stănescu et al., 2002; Stănescu et al.2002b; Yberrt et al., 2013; Council Directive 92/43/EEC; Romanian Pharmacopoeia; European Pharmacopoeia).

\section{Results and discussions}

\subsection{Medicinal plants recorded}

Two plant associations were identified: Festuco rubrae-Agrostietum capillaris Horvat 1951 and Poo-Trisetetum flavescentis Knapp ex Oberdorfer 1957.

They were classified according to Coldea (2012) as follows: Cls. MolinioArrhenatheretea, Ord. Arrhenatheretalia, All. 
Arrhenatherion Koch 1926, Ass. PooTrisetetum flavescentis Knapp $1951 \mathrm{em}$. Oberdorfer 1983; All. Cynosurion R.Tx.1947, Ass. Festuco- Agrostetum capillaris Horvat 1951.

The phytocoenosis of these two associations belong to $\mathbf{6 5 2 0}$ - Mountain hay meadows habitat of community interest listed in Annex I of Habitats Directive (Council Directive 92/43/EEC). The flora of these associations included many medicinal plants. We mention that the phytosociological surveys were recorded at different altitudes ranging between 504-1255 m, and 29 surveys were processed. A part of the plants identified in these surveys were medicinal species. Thus, in the Festuco rubrae-Agrostietum capillaris association 74 taxa out of 148 identified, contained certain therapeutic chemical compounds, while in the Poo-Trisetetum flavescentis association 57 taxa out of 141 identified, contained certain therapeutic chemical compounds.

The most common herbs, whose presence in phytosociologic surveys is very high (81100\%) are: Achillea millefolium, Plantago lanceolata, Prunella vulgaris and Trifolium pratense, followed by those with high frequency $(61-80 \%)$ : Alchemilla xanthochlora, Carum carvi, Equisetum arvense, Euphrasia rostkoviana, Pimpinella saxifraga, Plantago media, Rumex acetosella, Thymus pulegioides, Veronica chamaedrys, Viola tricolor etc. The following species have an average frequency between 41-60\%: Daucus carota, Fragaria vesca, Galium mollugo, Galium verum, Mentha longifolia, Polygala vulgaris, Potentilla erecta etc.

\subsection{Therapeutic uses of medicinal plants}

The medicinal plants were gathered according to the dominant active principles for which they are used in traditional medicine or phytotherapy. From the total medicinal species recorded in inventory, the most numerous species contain: tannins $(16,66 \%$ of the species), essential oils (12,22\% of the species), coumarins $(11,11 \%$ of the species $)$, flavonoids (10\% of the species), saponins $(8,88 \%$ of the species), alkaloids and mucilage (6,66\% each), iridoids, bitter compounds and organic acids, vitamins and provitamins $(4,44 \%$ each $)$ (Stănescu et al., 2002; Stănescu et al.2002b; Stănescu et al. 2004; Wright et al., 2007; Eşianu et Ștefãnescu, 2016) etc. (Table 1).

Table 1. Checklist of medicinal species used in traditional medicine and phytotherapy according to the dominant active principles

\begin{tabular}{|c|l|l|}
\hline \multirow{2}{*}{$\begin{array}{c}\text { The dominant } \\
\text { active principles }\end{array}$} & \multicolumn{1}{|c|}{ Species } & \multicolumn{1}{c|}{$\begin{array}{c}\text { Medicinal vegetal } \\
\text { products }\end{array}$} \\
\hline \multirow{4}{*}{ MUCILAGE } & Anchusa officinalis & Flos et folium \\
\cline { 2 - 3 } & Platago lanceolata & Folium \\
\cline { 2 - 3 } & Plantago major & Folium \\
\cline { 2 - 3 } & Plantago media & Folium \\
\cline { 2 - 3 } & Tussilago farfara & Folium \\
\cline { 2 - 3 } & Verbascum lychnitis & Flos \\
\hline \multirow{3}{*}{ PHENOLIC GLYCOSIDES } & Filipendula ulmaria & Flos \\
\cline { 2 - 3 } & Populus tremula & Gemma \\
\cline { 2 - 3 } & Salix alba & Cortex \\
\hline \multirow{2}{*}{$\begin{array}{c}\text { ANTHRAQUINONE } \\
\text { DERIVATIVES }\end{array}$} & Rumex acetosa & Herba \\
\cline { 2 - 3 } & Rumex acetosella & Herba \\
\cline { 2 - 3 } & Rumex crispus & Rhizoma \\
\hline NAPHTODIANTHRONES & Hypericum maculatum & Herba \\
\hline
\end{tabular}


Silvia Oroian et al.

\begin{tabular}{|c|c|c|}
\hline & Hypericum perforatum & Herba \\
\hline CARDIAC GLYCOSIDES & Digitalis grandiflora & Folium \\
\hline \multirow{8}{*}{ SAPONINS } & Bellis perennis & Flos \\
\hline & Equisetum arvense & Herba \\
\hline & Ononis arvensis & Radix \\
\hline & Polygala comosa & Herba \\
\hline & Polygala vulgaris & Herba \\
\hline & Primula veris & Rhizoma cum radicibus \\
\hline & Trifolium pratense & Flos \\
\hline & Viola tricolor & Herba \\
\hline \multirow{10}{*}{ FLAVONOIDS } & Crataegus monogyna & Folium, fructus et flos \\
\hline & Eupatorium cannabinum & Rhizoma et radix \\
\hline & Linaria vulgaris & Herba \\
\hline & Pilosella officinarum & Herba \\
\hline & Prunella vulgaris & Herba \\
\hline & Trifolium repens & Herba \\
\hline & Veronica chamaedrys & Herba \\
\hline & Veronica officinalis & Herba \\
\hline & Vincetoxicum hirundinaria & Radix \\
\hline & Viola tricolor & Herba \\
\hline \multirow{11}{*}{ COUMARINS } & Cruciata glabra & Herba \\
\hline & Cruciata laevipez & Herba \\
\hline & Galium mollugo & Herba \\
\hline & Galium verum & Herba \\
\hline & Heracleum sphondylium & Radix, folium et fructus \\
\hline & Medicago falcata & Herba \\
\hline & Medicago lupulina & Herba \\
\hline & Medicago sativa & Herba \\
\hline & Melilotus officinalis & Flos et herba \\
\hline & Pastinaca sativa & Radix \\
\hline & Pimpinella saxifraga & Radix \\
\hline \multirow{15}{*}{ TANNINS } & Agrimonia eupatoria & Herba \\
\hline & Alchemilla xanthochlora & Herba \\
\hline & Anthyllis vulneraria & Flos \\
\hline & Fragaria vesca & Folium \\
\hline & Fragaria viridis & Folium \\
\hline & Geranium robertianum & Herba \\
\hline & Geum urbanum & Rhizoma \\
\hline & Lysimachia nummularia & Herba \\
\hline & Lythrum salicaria & Herba \\
\hline & Polygonum bistorta & Rhizoma \\
\hline & Potentilla argentea & Rhizoma \\
\hline & Potentilla erecta & Rhizoma \\
\hline & Potentilla recta & Rhizoma \\
\hline & Potentilla reptans & Rhizoma \\
\hline & Salix alba & Cortex \\
\hline DEPSIDES & Cichorium intybus & Herba et radix \\
\hline \multirow{6}{*}{ ESSENTIAL OILS } & Achillea millefolium & Flos \\
\hline & Carum carvi & Fructus \\
\hline & Juniperus communis & Psudo-fructus \\
\hline & Mentha longifolia & Folium \\
\hline & Origanum vulgare & Herba \\
\hline & Petasites hybridus & Rhizoma \\
\hline
\end{tabular}




\begin{tabular}{|c|c|c|}
\hline & Picea abies & Turiones \\
\hline & Thymus glabrescens & Herba \\
\hline & Thymus pulcherrimus & Herba \\
\hline & Thymus pulegioides & Herba \\
\hline ALLANTOIN & Symphytum officinale & Radix \\
\hline GLYCORESINS & Convolvulus arvensis & Herba \\
\hline \multirow{5}{*}{ IRIDOIDS } & Ajuga reptans & Herba \\
\hline & Euphrasia rostkoviana & Herba \\
\hline & Lamium album & Herba \\
\hline & Stachys germanica & Herba \\
\hline & Stachys officinalis & Herba \\
\hline \multirow{6}{*}{ ALKALOIDS } & Clematis vitalba & Folium \\
\hline & Colchicum autumnale & Semen \\
\hline & Echium vulgare & Herba \\
\hline & Genista tinctoria & Herba \\
\hline & Senecio jacobaea & Herba \\
\hline & Veratrum album & Rhizoma \\
\hline \multirow{4}{*}{ BITTER COMPOUNDS } & Centaurium erythraea & Herba \\
\hline & Gentiana asclepiadea & Radix \\
\hline & Glechoma hederacea & Herba \\
\hline & Taraxacum officinale & Radix et herba \\
\hline $\begin{array}{l}\text { BITTER-AROMATIC } \\
\text { COMPOUNDS }\end{array}$ & Artemisia vulgaris & Herba \\
\hline \multirow{4}{*}{$\begin{array}{l}\text { ORGANIC ACIDS, VITAMINS } \\
\text { and PROVITAMINS }\end{array}$} & Daucus carota & Radix \\
\hline & Rosa canina & Fructus \\
\hline & Rubus idaeus & Folium \\
\hline & Urtica dioica & Folium \\
\hline
\end{tabular}

Inexhaustible green treasure of Gurghiului Mountains can be an important source of active ingredients for achieving herbal extracts used in various diseases. The most numerous herbs are used in disorders of the digestive system (37 sp.), respiratory system (18 sp.), skin disorders (15 sp.), muscular and skeletal systems (10 sp.) genitourinary system (8 sp.), in gynecological disorders (4 sp.), cardiovascular, CNS disorders and geriatrics (2 sp. each) (Table 2).

As shown in Table 2, the majority of plants were reported to be used for more than one type of disease.

Table 2. Medicinal plant species used in various disorders

\begin{tabular}{|c|c|c|}
\hline \multirow{3}{*}{$\begin{array}{l}\text { PHYTOTHERAPY FOR } \\
\text { DIGESTIVE SYSTEM } \\
\text { DISORDERS }\end{array}$} & $\begin{array}{l}\text { Phytotherapy of mouth } \\
\text { - } \text { gingivitis, } \\
\text { - } \text { stomatitis, thrush, } \\
\text { - } \text { periodontitis, } \\
\text { - } \quad \text { dental abscesses, } \\
\end{array}$ & $\begin{array}{l}\text { Achillea millefolium, Agrimonia } \\
\text { eupatoria, Centaurium erythraea, Geum } \\
\text { urbanum, Lysimachia nummularia, } \\
\text { Lythrum salicaria, Polygonum bistorta, } \\
\text { Potentilla sp., Thymus sp. }\end{array}$ \\
\hline & $\begin{array}{l}\text { Hyperacid gastritis and ulcer } \\
\text { disease }\end{array}$ & $\begin{array}{l}\text { Equisetum arvense, Hypericum } \\
\text { sp.,Medicago sativa, Melilotus } \\
\text { officinalis, Plantago sp., Rubus idaeus, } \\
\text { Symphytum officinale }\end{array}$ \\
\hline & $\begin{array}{l}\text { Gastric hypoacidity - } \\
\text { dyspepsia, anorexia }\end{array}$ & $\begin{array}{l}\text { Artemisia vulgaris, Centaurium } \\
\text { erythrea, Euphrasia rostkoviana, } \\
\text { Gentiana asclepiadea }\end{array}$ \\
\hline
\end{tabular}




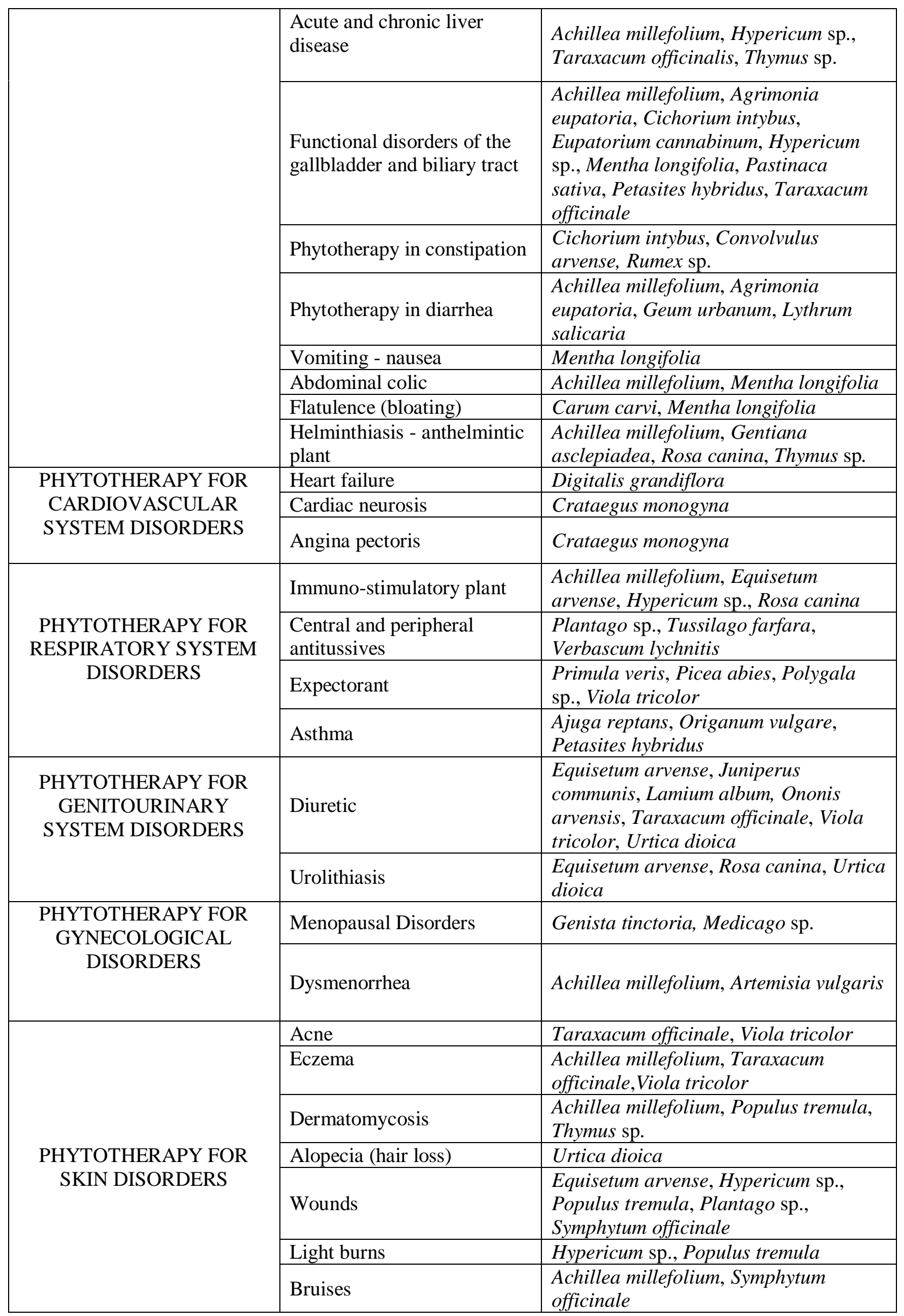




\begin{tabular}{|c|l|l|}
\hline $\begin{array}{c}\text { PHYTOTHERAPY FOR } \\
\text { LOCOMOTORY SYSTEM } \\
\text { DISORDERS }\end{array}$ & $\begin{array}{l}\text { Plant products with anti- } \\
\text { inflammatory / analgesic, } \\
\text { anti-rheumatic and } \\
\text { hyperemic action }\end{array}$ & $\begin{array}{l}\text { Hypericum sp., Juniperus communis, } \\
\text { Medicago sativa, Mentha longifolia, } \\
\text { Picea abies, Populus tremula, Salix } \\
\text { alba, Taraxacum officinale, Urtica } \\
\text { dioica }\end{array}$ \\
\hline $\begin{array}{c}\text { PHYTOTHERAPY FOR } \\
\text { CNS SYSTEM DISORDERS }\end{array}$ & $\begin{array}{l}\text { Sleep disturbances; } \\
\text { Nervousness; Depression. }\end{array}$ & Hypericum sp. \\
\hline $\begin{array}{c}\text { PHYTOTHERAPY IN } \\
\text { GERIATRY }\end{array}$ & Crataegus monogyna, Urtica dioica \\
\hline
\end{tabular}

There is major interest in the health benefits of herbs and botanicals (Foote et Cohen, 1998). In the same time, there are an increasing number of papers claiming that plants or plant-derived active principles may function as agent against many human diseases. Most of these researches have determined the level of clinical support for the traditional use of common or folklore medicines. Many plant species are known as sources of treating human ailments, this study documents the plants from Gurghiului Mountains, used in Romania by traditional healers for the treatment of different human disease.

Our study confirms that wild medicinal plants and natural products obtained from these are still a major source of medicine for the people living in the studied area.

\section{Conclusions}

The medicinal plants generally have significant less adverse effects compared with synthesized substances and also people have a better tolerance to these plants than synthetic drugs. In this paper we summarize information on medicinal and aromatic plants with current information in the international literature and highlight the current state of ethnopharmacological, phytochemical and clinical research on some of the more widely used and better known species. Mountain hay meadows from Gurghiului Mountains can be an important source of active substances for achieving herbal extracts used in various diseases, but it can also provide a comparative basis for future similar floristic research to be carried out in the Eastern Carpathians.

The most numerous herbs identified in study area are those used for: disorders of the digestive, respiratory, dermatological disorders, musculoskeletal and urogenital systems. Further experimental investigation of these medicinal and aromatic plants may possibly offer effective and alternative affordable management of some human disease.

\section{Conflict of Interest}

The authors declare that the research was conducted in the absence of any commercial or financial relationships that could be construed as a potential conflict of interest.

\section{References}

1. Aguilar-Støen M, Moe SR (2007) Medicinal plant conservation and management: distribution of wild and cultivated species in eight countries. Biodivers Conserv 16:1973-1981.

2. Ciulei I, Grigorescu E, Stănescu U (1993) Medicinal herbs, Phytochemistry and phytotherapy, vol. 2. Medical Publishing House, București

3. Coldea Gh (red). (2012) Les associations végétales de Roumanie, tom 2. Les associations herbacées anthropogène. Cluj University Press, Cluj-Napoca 
4. Cristea V, Gafta D, Pedrotti F (2004) Phytosociology. Cluj University Press, Cluj-Napoca

5. De Smet P (1997) The role of plantderived drugs and herbal medicines in healthcare. Drugs 54(6):801-840.

6. Doniţă N, Popescu A, Paucă-Comănescu M, Mihăilescu S, Biriş IA (2005) Habitats from Romania. Silvic Technical Publishing House, București, 2005

7. Eşianu S, Ştefănescu R (2016) Phytotherapy. University Press, Tîrgu Mureș

8. Foote J, Cohen B (1998) Medicinal herb use and the renal patient. J Renal Nutr 8:4042.

9. Gafta D, Mountford O (eds) (2008) Handbook for the interpretation of Natura 2000 habitats in Romania. Risoprint Publishing House, Cluj-Napoca

10. Istudor V (1998) Pharmacognosy, Phytochemistry, Phytotherapy, vol. 1. Medical Publishing House, Bucureşti

11. Istudor V (2001) Pharmacognosy, Phytochemistry, Phytotherapy, vol. 2. Medical Publishing House, Bucureşti

12. Nadembega P, Boussimb JI, Nikiemac JB, Poli F, Antognoni F (2011) Medicinal plants in Baskoure, Kourittenga Province, Burkina Faso: An ethnobotanical study. J Ethnopharmacol 133:378-395.

13. Nkomo MM, Katerere DD, Vismer HH, Cruz TT, Balayssac SS, Malet-Martino MM, Makunga NN (2014) Fusarium inhibition by wild populations of the medicinal plant Salvia africana-lutea L. linked to metabolomic profiling. BMC Complem Altern M 14:99-105.

14. Oroian S (1998) Flora and vegetation of the Mureş Gorge between Toplita and Deda. Mures Publishing House, Tîrgu Mureş

15. Oroian S (2011) Botanical Pharmaceuticals. University Press, Tîrgu Mureş, 2011
16. Oroian S, Sămărghiţan M (2000) The medicinal plants from the spontaneous flora of the Mureş Gorge between Toplita and Deda. Acta Horti Botanici Bucurestiensis 2:91-198.

17. Palade M (1998) Pharmaceutical botany. Systematic plant, vol.2. Technical Publishing House, Bucureşti

18. Palade M, Dinu M, Stamanichi M, Codreanu MV, Pavel M (2003) Phytotaxonomy - practical bases. București. Tehnoplast Company Publishing House, București

19. Rácz, Rácz KE， Szabó LGy (2012) Gyógynövények ismerete. A fitoterápia és az alternativ medicina alapjai. Galenus, Budapesta

20. Sămărghiţan M (2005) The flora and vegetation of Gurghiului Valley. University Press, Tîrgu Mureş

21. Sămărghiţan M, Oroian S (1999) Inventory of medicinal plants from Gurghiului Valley. Note Botanice, Tîrgu Mureş 25:4360.

22. Stănescu U, Miron A, Hănceanu M, Aprotosoaie C (2002) The pharmaceutical, pharmacological and clinical basics of phytotherapy, vol. 1. „Gr.T.Popa“, Iaşi Publishing House, Iași

23. Stănescu U, Miron A, Hănceanu M, Aprotosoaie C (2002) The pharmaceutical, pharmacological and clinical basics of phytotherapy, vol.2. „Gr.T.Popa“ UMF Iaşi Publishing House, Iași

24. Stănescu U, Miron A, Hăncianu M, Aprotosoaie C (2004) Medicinal herbs from A to Z. Monographs of products of therapeutic interest, vol. 1-2, „Gr.T.Popa“ UMF Iaşi Publishing House, Iaşi

25. Tahraoui A, El-Hilaly AJ, Israili ZS, Lyoussi B (2007) Ethnopharmacological survey of plants used in the traditional treatment of hypertension and diabetes in 
south-eastern Morocco (Errachidia province). J Ethnopharmacol 110:105-117.

26. Tămaș M., Pharmaceutical botany. Systematica - Cormobionta, vol.3, Medical University "Iuliu Haţieganu" Publishing House, Cluj-Napoca, 1999; 19-254.

27. Tiță I (2003) Pharmaceutical botany. Didactic and Pedagogical Publishing House, București

28. Wright C., Van-Buren L, Kroner CI, Koning MG (2007) Herbal medicines as diuretics: A review of the scientific evidence. J Ethnopharmacol 114:1-31.

29. Yberrt E, Delesalle-Feat T (2013) Larousse des Plantes Medicinales-Identification, preparation, soins, ed. II., Encyclopedia of Medicinal Plans Publishing House, Franţa

30. *** Council Directive 92/43/EEC of 21 May 1992 on the conservation of natural habitats and of wild fauna and flora.

31. *** Farmacopeea Română. 1993. Editia a X-a, Medical Publishing House, Bucureşti

32. *** European Pharmacopoeia $8^{\text {th }}$ edition, 2014. 